\title{
AGENTES PENITENCIÁRIOS APRISIONADOS EM SUAS REDES? *
}

\section{Ludmila Mendonça Lopes Ribeiro (1)}

https://orcid.org/0000-0003-4304-2254

\section{Victor Neiva e Oliveira ${ }_{(2)}$}

https://orcid.org/0000-0002-6563-3349

\section{Neylson Crepalde}

https://orcid.org/0000-0003-4062-5008

\section{Luiza Meira Bastos}

https://orcid.org/0000-0002-4084-5556

\section{Yolanda Campos Maia}

(i) https://orcid.org/0000-0002-4462-964X

(1) Universidade Federal de Minas Gerais (UFMG), Belo Horizonte-MG, Brasil. E-mail: ludmila.ribeiro@gmail.com

(2) Universidade Federal de São João Del Rei (UFSJ), São João Del Rei - MG, Brasil. E-mail: victorneivaeoliveira@yahoo.com.br

(3) Instituto Izabela Hendrix, Belo Horizonte - MG, Brasil. E-mail: neylsoncrepalde@gmail.com

(4) Instituto de Estudos Políticos e Sociais (IESP), Rio de Janeiro - RJ, Brasil. E-mail: bastosm.luiza@gmail.com

(5) Universidade Federal de Minas Gerais (UFMG), Belo Horizonte - MG, Brasil. E-mail: yolandacamposmaia@gmail.com

DOI: $10.1590 / 3410115 / 2019$

\section{Introdução}

O trabalho desenvolvido pelos agentes penitenciários nas prisóes requer, normalmente, que eles se coloquem em um estado permanente de alerta. Suas atividades precípuas são vigiar, desconfiar e controlar; tarefas indispensáveis para a manutenção da ordem, em um ambiente adverso e imprevisível (Arnold, 2016; Cloward, 1968; Kauffman, 1981; Lombardo, 1989). Para desempenho eficiente dessas funçóes, tais trabalhadores precisam ficar próximos dos presos (Tait, 2011), lidar de maneira habilidosa com as infraçóes disciplinares (Hawkins, 1976), impedir a eclosão de situações violentas nas celas (Duffee, 1974) e antecipar-se às

* O presente trabalho foi desenvolvido com o apoio do CNPq, sob o processo número 445545/2014-3.

Artigo recebido em: 20/09/2017

Aprovado em: 11/04/2019 tentativas de motins ou rebeliôes arquitetadas pelos internos (King, 2009).

Algumas pesquisas sobre as especificidades do trabalho de custódia, executado pelos agentes penitenciários, têm mostrado que o estado de alerta requerido para a manutenção da ordem na prisão cristaliza-se de tal modo, que eles não conseguem "sair do papel”, mesmo quando fora da penitenciária (Arnold, 2005, Crawley, 2004; Moraes, 2005; Roseira, 2018). Os "danos" provocados pela experiência de "confinamento" àqueles que trabalham nas prisóes são tamanhos, que alguns chegam a denominá-los de aprisionamento (Liebling et al., 2018). Todavia, este é um tema relativamente novo na sociologia das prisôes, já que os estudos clássicos sobre dinâmicas prisionais têm como foco analítico prioritário os efeitos da experiência de aprisionamento sobre os internos (Lourenço e Alvarez, 2017).

De acordo com os estudos prisionais clássicos, o processo de imersão na vida prisional promoveria 
mudanças tão substanciais no comportamento dos internos, que eles sentiriam profundas dificuldades em se adaptar novamente à vida extramuros, após o período de cumprimento de pena (Clemmer, 1940; 1950; Sykes, 1965; Sykes e Messinger, 1960; Goffman [1961] 2007). No interior das prisões, eles passariam pela "mortificação do eu" e pelas "dores do aprisionamento", ${ }^{2}$ experiências que levariam à "prisionização". 3 O resultado mais imediato deste processo seria a internalização de um sistema de crenças, valores e atitudes, que deixaria o "prisioneiro" relativamente imune à influência de um sistema de valores convencional (Clemmer, 1940; Clemmer, 1950), impedindo o funcionamento de qualquer programa de ressocialização (Akers et al., 1977; Wheeler, 1961).

A partir da década de 1980 , o foco analítico dos estudos sobre prisóes foi progressivamente redirecionado para o universo dos guardas, na tentativa de compreender como eles poderiam ser afetados pelo trabalho na linha de frente das prisóes (Hepburn, 1989; Lombardo, 1989). Tais pesquisas partiram do pressuposto de que, assim como os presos, os guardas também poderiam sofrer algum tipo de adaptação ao ambiente prisional (Kauffman, 1981), ao lidarem com as demandas do trabalho, como as "dores do aprisionamento" vivenciadas pelos prisioneiros (Roseira, 2018), o que levaria ao desenvolvimento de estratégias de sobrevivência ou de segurança pessoal (Crawley, 2004).

Essas análises passaram a evidenciar como se dá a formação de uma "subcultura custodial", enquanto uma estratégia de autoproteção dos guardas (Duffee, 1974). Os agentes prisionais tenderiam a se constituir como um grupo fechado, em razão da progressiva absorção de certas dimensóes da linguagem carcerária, como estratégia para manter a proximidade com os detentos (Monteiro e Araújo, 2018), afastar as consequências desumanizadoras do uso excessivo de poder (Zimbardo, 2007), e atenuar o conflito de papéis entre segurança ou reabilitação (Hepburn e Albonelli, 1980); além de evitar os problemas de saúde física e mental, visíveis em sintomas como cansaço, estresse, síndrome de burnout $^{4}$ e depressão (Schaufelli e Peeters, 2000; Dowden e Tellier, 2004; Bezerra et al., 2016).

Por sua vez, os prejuízos emocionais, decor- rentes do "controle das emoçóes", no contato diário com os presos (Crawley, 2004), teriam como consequência o "endurecimento" (frieza, tristeza e agressividade) gradual desses trabalhadores (Claus, 2012), que se absteriam de conviver com diferentes segmentos, centrando suas redes de contato em colegas de trabalho e em alguns presos, configurando-se, assim, uma espécie de aprisionamento (Arnold, 2005).

Essa mesma literatura destaca que os efeitos do trabalho custodial se tornam prementes em contextos de mudanças, como aqueles pelos quais têm passado o sistema penitenciário brasileiro (Moraes, 2013; Dias, 2017) e, especificamente, o mineiro (Lourenço, 2010; Oliveira, 2018), com o aumento da superlotação e a expansão das redes de crime organizado, como o Primeiro Comando da Capital (Dias, 2017; Silvestre, 2012; Godoi, 2017). Neste cenário, os agentes precisam se antecipar aos desmandos dos grupos desviantes, o que requer maior habilidade para interlocução com as lideranças prisionais (Moraes, 2013). Por outro lado, a pressão constante para a corrupção da autoridade (Sykes, 1965) faz com que a custódia passe a ter mais especificidades, podendo resultar em maior sobrecarga de trabalho, além de outros efeitos perversos (Lourenço e Alvarez, 2017).

No presente artigo, procuramos desvelar como se conformam as redes pessoais dos agentes prisionais e, caso suas interaçóes sejam mais restritas ao ambiente prisional, analisar em que medida tal fenômeno pode ser entendido como um efeito do trabalho custodial e, por conseguinte, indicativo do aprisionamento. Para tanto, utilizaremos os dados coletados a partir de entrevistas com 13 agentes prisionais e 16 presos, alocados em unidades penitenciárias da Região Metropolitana de Belo Horizonte (RMBH), entre os anos de 2015 e 2017.

\section{O trabalho dos agentes penitenciários: um breve balanço da literatura}

Os agentes penitenciários são funcionários responsáveis pela vigilância e controle dos presos. Realizam atividades rotineiras de inspeção das celas, verificação dos cadeados e controle da entrada e saída 
dos estabelecimentos prisionais (King, 2009). Exercem essas funções em permanente interação com os presos, razão pela qual exige-se a constante tomada de decisôes e o "exercício da autoridade" (Hepburn, 1985), mesmo sendo ilusório acreditar que a simples autoridade conferida pelo cargo seja suficiente para manter a ordem na prisão (Sykes, 1965).

Ao lidarem com os prisioneiros, os guardas abrem mão, em certa medida, do "poder total" do qual estão investidos para desempenhar de maneira eficiente as suas atividades (Lombardo, 1989). Por isso, qualquer ato impensado ou mal calculado pode minar a sua credibilidade, dilatar as possibilidades de fuga e colocar a ordem prisional em colapso (Tait, 2011). Recorrer ao uso da força física, ou aplicar puniçóes a qualquer tipo de comportamento disruptivo dos internos, podem gerar insatisfaçóes (Liebling, 2000), além de tornarem o trabalho árduo e mais cansativo (King, 2009). Para discernir adequadamente em que circunstâncias é preciso exercer poder, e quais situaçóes podem ser administradas por outros métodos, os agentes precisam desenvolver uma relação intrínseca com os cativos (Marquart, 1986).

Ao mesmo tempo em que se demanda o distanciamento desses profissionais, (Liebling et al., 2018), a proximidade entre os membros deste staff e os detentos (Hepburn e Crepin, 1984; Liebling, 2000) constitui a única forma de garantir a cooperação dos presos, para a manutenção da "paz nas prisóes”. Constrói-se, assim, uma relação paradoxal no exercício rotineiro das atividades custodiais, implicando em "acordos tácitos", compromissos recíprocos entre os dois grupos, negociaçóes com as lideranças de presos, ${ }^{5}$ e, por vezes, tensóes e conflitos com a população prisional e com os próprios pares (Freitas, 1985). A produção desse "equilíbrio precário" requer o aprendizado de habilidades específicas, por parte dos agentes, no sentido de conquistar a cooperação dos presos e manter, ao mesmo tempo, a sua autoridade (Sykes, 1965; Coelho, 2005).

Nas suas atividades de vigilância, os agentes são instruídos a manter certo "distanciamento" em relação aos presos, de modo a evitar qualquer tipo de envolvimento mais íntimo e pessoal (Monteiro e Araújo, 2018). Um agente não pode se tornar muito "amigo" de um preso, sob o risco de gerar desconfiança por parte da administração e tornar-se um "pária" entre o seu grupo (Paixão e Coelho, 1984). A busca dos presos por proximidade também pode ser interpretada como uma estratégia para corromper a autoridade dos agentes (Sykes, 1965), levando-os a procurar evitar contato corporal e a estar sozinhos com os detentos, no interior das celas (Moraes, 2005).

Nesse processo de interaçáo constante, a grande preocupação do agente é a de não se igualar ao preso, desenvolvendo, assim, várias estratégias para evitar os "perigos da contaminação" (Freitas, 1985) no desempenho do seu papel. Entre os agentes, existe o temor de começarem a assimilar progressivamente os principais elementos da chamada "cultura cativa" (gírias, modo de falar, de se comportar e de lidar com as situaçóes), em razão do contato contínuo nos pavilhóes (Moraes, 2005; Lourenço, 2010). Logo, o guarda deve aprender a lançar mão estrategicamente da semelhança - em termos de vocabulário e de gestos -, em determinadas situaçóes, para garantir a tranquilidade nos pavilhôes (Monteiro e Araújo, 2018); e, em situaçóes de desrespeito por parte dos presos, deve reforçar a sua autoridade, sem demonstrações excessivas de força ou violência física (Cloward, 1968; Hepburn, 1985).

Esse aprendizado de quais situaçóes precisam ser resolvidas pela igualdade, e quais devem ser resolvidas com o recurso à autoridade, tem enorme custo para os agentes (Tait, 2011). Qualquer atitude percebida como suspeita, pelos seus pares, pode trazer sérios prejuízos profissionais e de convivência (Liebling et al., 2011), razão pela qual eles são coagidos pelo grupo profissional a aderir aos valores de solidariedade, coragem, resiliência e autoritarismo do coletivo profissional (Crawley, 2004). Essa aquiescência às normas do grupo envolve um longo processo de aprendizagem com os pares (Bandeira e Batista, 2009; Lombardo, 1989; Paixão e Coelho, 1984).

Normalmente, nos primeiros meses de trabalho nas prisóes, os agentes novatos são ensinados a ocultar suas emoçóes (ansiedade, medo, angústia e depressão), para não serem desacreditados pelos colegas e percebidos como "frágeis" pelos presos (Tait, 2011), de modo a desempenharem seus papéis sem "desvios" comportamentais aparentes (Crawley e Crawley, 2008). São instruídos pelos agentes mais 
antigos a se manter em um estado permanente de alerta (Roseira, 2018), orientando sua ação para a tríade "vigilância, desconfiança e controle", que tende a transbordar para além dos muros da prisão (Arnold, 2008). A desconfiança, por exemplo, deve ser também estendida aos colegas (Moraes, 2005). A vigilância do comportamento diário dos pares representa uma forma de impedir a entrada de objetos ilícitos (armas, celulares ou drogas), que podem colocar em risco a vida dos agentes, a segurança da unidade prisional e a própria imagem pública da profissão (Moraes, 2013). Ela é, então, uma forma de controle sobre o próprio grupo profissional.

No cotidiano da vida prisional, os agentes penitenciários precisam lidar com situações de violência física, suicídios e ameaças, e com as possibilidades de eclosão de desordens coletivas nas prisóes (Lourenço, 2010). Tais situações colocam os agentes em um contexto de trabalho permeado pelo medo, pelo risco e pela incerteza (Crawley, 2014), podendo levar ao stress ocupacional, cujo reflexo principal consiste na dificuldade em lidar com os presos (Bezerra et al., 2016), com os próprios colegas de profissão (Nascimento et al., 2019) e com os familiares (Schaufelli e Peeters, 2000).

A constante tensão no ambiente de trabalho pode também afetar a vida do agente fora das prisóes, sobretudo, no que diz respeito às dificuldades de "sair do papel" de guardião do ambiente prisional (Lourenço, 2010). O estado de alerta constantemente vivenciado nas atividades intramuros acaba sendo "transferido" para as extramuros, (Oliveira et al., 2015), tornando-se visível, por exemplo, no medo de ser vitimado em locais públicos, ser perseguido nos trajetos do trabalho para a casa, de ter a sua profissão descoberta, de sofrer preconceito pelo público externo, e na sensação de insegurança constante ao transitar por diferentes espaços fora das prisóes (Moraes, 2013; Nascimento, 2019).

$\mathrm{Na}$ literatura internacional, há certo consenso de que a natureza da atividade custodial promove efeitos duradouros no comportamento desses indivíduos, a ponto de eles serem "guardas" nas diferentes situaçóes que venham a vivenciar, mesmo quando estão em casa ou nas ruas (Liebling et al., 2011). Arnold (2005), por exemplo, mostrou como os agentes costumam checar infalivelmente se as portas das suas casas e seus cadeados estão devidamente trancados. Quando estâo em locais fechados, soem contar o número de pessoas em uma sala, confrontar problemas que venham a surgir, e direcionar a atenção para qualquer ruído estranho, tais como barulhos de telefones ou alarmes, ou um silêncio não muito característico. ${ }^{6} \mathrm{E}$ nas conversas com pessoas estranhas ou com familiares, eles continuam a proceder como se estivessem na custódia, explicando as situações de maneira vigorosa e assertiva.

Portanto, as múltiplas pressóes que são exercidas sobre os agentes penitenciários - seja em termos de proximidade e distanciamento em relação aos internos, de controle das emoçóes perante os colegas e os detentos, de estado permanente de alerta frente ao risco iminente, ou ainda, de capacidade de discernir situações limítrofes de eventos rotineiros -, podem gerar neles um processo de isolamento social progressivo (Liebling e Maruna, 2005; Roseira, 2018). Esses efeitos seriam visíveis tanto na redução de suas redes de contatos, que ficariam mais restritas àqueles que vivenciam situação semelhante (outros agentes), como também no constante temor à vitimizaçáo pessoal e de seus familiares (Morris e Morris, 1962; Steiner e Wooldredge, 2016).

Essas alteraçóes no comportamento dos agentes, com a restrição de sua rede de contatos a sujeitos que também vivenciam o ambiente penitenciário, é o que denominamos, no contexto do presente artigo, de aprisionamento. Partimos do pressuposto de que a maior restriçáo da rede de contato dos agentes prisionais seria um dos efeitos da dificuldade de "sair do papel", exercendo-o mesmo quando fora do ambiente de trabalho. Resta saber como este fenômeno se configura entre os agentes prisionais da RMBH.

\section{Metodologia}

Os dados apresentados, neste artigo, são parte da pesquisa "Quem são, como vivem e com quem se relacionam os presos da Região Metropolitana de Belo Horizonte", financiada pelo CNPq (processo 445545/2014-3) e autorizada pelo Comitê de Ética em Pesquisa (CAAE 47198415.3.0000.5149). 
Entre 2003 e 2017, a população prisional mineira passou de 23.298 para 68.354 presos, tornando-se a segunda maior do país (Depen, 2017), ${ }^{7}$ em que pese a quantidade de vagas ter permanecido estável, representando uma taxa de ocupação de 200\% (FBSP, 2018). Para guardar esse contingente, o governo estadual investiu em concursos públicos para a contratação de novos agentes penitenciários, que passaram de 650, em 2003, para 17.082 indivíduos, em 2017 (Oliveira, 2018). Trata-se, então, de um contexto de superlotaçáo e de aumento da quantidade de funcionários empregados na atividade de custódia.

A Região Metropolitana de Belo Horizonte concentra $1 / 3$ de toda a população prisional do estado de Minas Gerais e, por conseguinte, uma parcela considerável de agentes prisionais exerce seu trabalho nessas cidades. Esse espaço geográfico é de interesse sociológico, por concentrar uma enorme diversidade de unidades prisionais, que incluem desde estabelecimentos específicos para mulheres gestantes até os presídios reservados para presos transexuais e homossexuais, que, enquanto vítimas preferenciais de agressóes de cunho sexual, precisam ser segregados dos demais.

Em dois anos de pesquisa (2015-2017), sete prisões da Região Metropolitana de Belo Horizonte foram visitadas na tentativa de entendermos as rotinas de vivência e de trabalho de presos e de agentes prisionais, respectivamente. Além da observação direta dessas dinâmicas, realizamos 29 entrevistas em profundidade (13 com agentes e $16 \mathrm{com}$ presos) e aplicamos questionários sociométricos junto a estes dois segmentos (Tabela 1).

Inicialmente, a proposta consistiu em vivenciar a rotina prisional e entrevistar, pelo menos, um preso e um agente. Dependendo da complexidade da dinâmica de encarceramento da unidade - como é o caso da Penitenciária Professor Jason Soares Albergaria, que abriga presos transexuais e homossexuais -, eram coletados novos depoimentos. As prisōes com mais de 300 presos (como a Penitenciária José Maria

Tabela 1

Entrevistas em Profundidade, Realizadas por Tipo de Estabelecimento, Durante a Primeira Fase da Pesquisa

\begin{tabular}{|c|c|c|c|c|}
\hline \multirow[t]{2}{*}{ Unidade } & \multirow[t]{2}{*}{$\begin{array}{l}\text { Características da unidade } \\
\text { Agente }\end{array}$} & \multicolumn{2}{|c|}{$\begin{array}{l}\text { Quantidade de } \\
\text { entrevistas }\end{array}$} & \multirow[t]{2}{*}{ Total } \\
\hline & & Pre & & \\
\hline $\begin{array}{l}\text { Presídio de São Joaquim de Bicas } \\
\text { II }\end{array}$ & $\begin{array}{l}\text { Prisão relativamente nova } \\
\text { (menos de } 15 \text { anos de funcionamento) }\end{array}$ & 3 & 2 & 5 \\
\hline $\begin{array}{l}\text { Centro de Remanejamento de } \\
\text { Presos Provisórios (CERESP) - } \\
\text { Gameleira }\end{array}$ & $\begin{array}{l}\text { Centro de Remanejamento, } \\
\text { com presos provisórios, preferencialmente }\end{array}$ & 1 & 2 & 3 \\
\hline $\begin{array}{l}\text { Penitenciária Professor Jason } \\
\text { Soares Albergaria }\end{array}$ & $\begin{array}{l}\text { Prisão com pavilhão exclusivo } \\
\text { para presos transexuais e/ou homossexuais }\end{array}$ & 3 & 3 & 6 \\
\hline $\begin{array}{l}\text { Complexo Penitenciário Nelson } \\
\text { Hungria }\end{array}$ & Prisão de segurança máxima & 1 & 2 & 3 \\
\hline $\begin{array}{l}\text { Complexo Penitenciário Estevão } \\
\text { Pinto }\end{array}$ & Prisão feminina mais antiga do estado & 1 & 4 & 5 \\
\hline Penitenciária José Maria Alkmin & Prisão masculina mais antiga do estado & 3 & 2 & 5 \\
\hline Presídio Regional de Santa Luzia & $\begin{array}{l}\text { Cadeia da Polícia Civil transferida } \\
\text { para o Sistema Prisional, nos últimos anos }\end{array}$ & 1 & 1 & 2 \\
\hline Total & & 13 & 16 & 29 \\
\hline
\end{tabular}

Fonte: Rede nas prisóes da RMBH (2015-2017). 
Alkmin, com mais de 2.000 detentos, e o Presídio de São Joaquim de Bicas II, com 600 internos) contam com uma quantidade maior de entrevistados, do que aquelas com poucos detentos (como o Presídio Regional de Santa Luzia, com 60 detentos), visto que a proposta dessas entrevistas era fornecer um panorama mais geral da unidade, o que seria impossível entrevistando apenas dois indivíduos.

A metodologia adotada para a coleta dos depoimentos consistia no uso de um roteiro semiestruturado de entrevista, procurando reconstituir a trajetória do entrevistado e sua rotina dentro da unidade prisional, com algumas questóes relativas à formação de redes de solidariedade. Ao final da conversa, era aplicado o questionário sociométrico, com vistas a reconstituir a rede de contatos pessoais do entrevistado. Presos e agentes eram solicitados a gerar uma lista de nomes, com a identificação da natureza do vínculo (se forte ou fraco) e da classificação de cada pessoa em seus respectivos grupos de referência (família, amigos, vizinhos, colegas de profissão), especificando, além disso, se a mesma também se encontrava encarcerada, ou não.

Os dados coletados por meio desses instrumentos indicam que o perfil dos dois grupos de entrevistados (presos e agentes) é muito semelhante, inclusive em termos socioeconômicos, já que ambos são oriundos das mesmas classes sociais (Moraes, 2005; Tait, 2011; Darke e Karam, 2016). Os dois grupos são compostos majoritariamente por homens, ${ }^{8}$ com idade média de 33 anos (agentes) e 36 anos (presos). Em termos de vivência na prisão, os agentes eram mais antigos do que os presos: média de 7,3 anos (aqueles) versus 4 anos (esses).

Todas as entrevistas foram transcritas e analisadas no software $\mathrm{N}$-vivo. Em seguida, as redes pessoais desses sujeitos foram reconstituídas. A partir da geração dos nomes com quem o entrevistado mantinha contato e da identificação dos mesmos em seu grupo de referência, reconstituímos as suas interaçôes; e, com a digitação desses dados no formato de uma planilha de Excel, analisamos a quantidade e a intensidade dessas interaçóes. (Wasserman e Faust, 1984, Marques et al., 2007; Lazega e Higgins, 2014).

Inicialmente, o ator central (no caso, o entrevistado) - chamado de ego - foi conectado com os outros sujeitos por ele mencionados, denominados de alters (Merlini, 2014). Em seguida, desenhamos graficamente "o conjunto de contatos de um dado indivíduo em sua sociabilidade, incluindo vínculos diretos e indiretos (os amigos e os amigos dos amigos, por exemplo)" (Marques e Bichir, 2011, p. 66). Como as "redes pessoais não se restringem apenas aos contatos imediatos dos indivíduos (redes egocentradas ou egonets), mas também levam em conta as relaçóes estabelecidas a partir desses contatos, num âmbito de sociabilidade mais amplo" (Marques et al., 2007, p. 2), conectamos também as relaçóes estabelecidas entre os alters, para além do ego.

A partir dessa metodologia de análise das redes pessoais, pudemos investigar a articulação da estrutura relacional imediata dos agentes penitenciários, e compará-las às dos presos. Em princípio, as redes pessoais de agentes deveriam ser maiores, mais diversas e esparsas, posto que, se comparados com os presos (impedidos legalmente de sair das unidades prisionais), eles transitam pelos mundos interno e externo às prisóes. Todavia, os estudos sobre agentes prisionais informam que, pelas dificuldades desses profissionais em "sair do papel", eles tendem a se inserir em um universo de sociabilidade menor e mais restrito ao ambiente penitenciário. Em qual extremo os agentes prisionais mineiros se encontram é o tema da próxima seção.

\section{Redes pessoais de presos e agentes: há diferenças?}

Nas prisões, dois grupos - presos e agentes penitenciários - mantêm contato direto e contínuo (Thompson, 1980; Paixão e Coelho, 1984; Moraes, 2005; Oliveira, 2018). Cada qual possui papéis organizacionais bem definidos, interesses inerentemente conflitantes, e ambos são regidos por diferentes "códigos de conduta", que prescrevem as maneiras e os modos esperados de cada qual (Cloward, 1968; Goffman, 2007; Kauffman, 1981). São esses códigos que irão orientar com quem presos e agentes devem interagir e como o contato deve ocorrer - o que pode ser verificado a partir da análise das redes pessoais. 
Tabela 2

Tamanho das Redes de Relacionamento dos Presos e Agentes Entrevistados

\begin{tabular}{|c|c|c|c|c|c|}
\hline \multirow{2}{*}{$\begin{array}{l}\text { Agentes } \\
\text { Reduzida }\end{array}$} & & \multicolumn{3}{|c|}{ Tamanho da rede } & \multirow[b]{2}{*}{ Total } \\
\hline & & Intermediária & Ampliada & & \\
\hline \multirow{3}{*}{ Não } & $\mathrm{N}$ & 150 & 119 & 116 & 385 \\
\hline & $\%$ & $39,0 \%$ & $30,9 \%$ & $30,1 \%$ & $100,0 \%$ \\
\hline & $\mathrm{N}$ & 115 & 61 & 47 & 223 \\
\hline \multirow[t]{2}{*}{ Sim } & $\%$ & $51,6 \%$ & $27,4 \%$ & $21,1 \%$ & $100,0 \%$ \\
\hline & $\mathrm{N}$ & 265 & 180 & 163 & 608 \\
\hline Total & $\%$ & $43,6 \%$ & $29,6 \%$ & $26,8 \%$ & $100,0 \%$ \\
\hline
\end{tabular}

Qui-quadrado:10,071 (0,007)

Fonte: Rede nas prisões da RMBH (2015-2017).

A primeira métrica desta análise é a quantidade de indivíduos inseridos nessas redes (Wasserman e Faust, 1984). Os 13 agentes penitenciários entrevistados (egos) possuem 223 conexóes com outros indivíduos (alters), o que significa uma média de 17 conexóes por agente (ou 17 alters por ego). Os 16 presos entrevistados geraram 385 conexóes; ou seja, uma média de 24 conexóes por preso. Utilizando as médias de alters por ego, verificamos que as redes dos presos comportam mais alters do que as dos agentes.

Em seguida, as redes pessoais dos entrevistados foram classificadas de acordo com o seu tamanho (Tabela 2) em: reduzidas (até 10 membros), intermediárias (entre 11 e 20 membros) e ampliadas (acima de 21 membros). Mais da metade dos agentes têm redes classificadas como de tamanho reduzido $(51,6 \%)$, enquanto quase $1 / 3$ dos detentos têm redes ampliadas $(30,1 \%)$.

Constatamos, assim, que as redes de relacionamento dos agentes são mais reduzidas do que as dos detentos, ainda que eles estejam privados de liberdade e não possam circular livremente em sociedade. A percepção dos agentes é a de que eles estão mais aprisionados do que os próprios detentos, o que foi destacado em vários momentos das entrevistas realizadas.

Inclusive, durante o questionário sociométrico, alguns agentes classificaram seus colegas como presos, designação que náo foi revista no processo de análise de dados para a preservação da informação original. Dos 86 colegas de profissão citados pelos agentes entrevistados, 75 foram por eles classificados como presos, algo que não ocorreu entre os internos ouvidos na pesquisa, que categorizaram os agentes como sujeitos que estão livres.

Essa ressalva é importante para o entendimento da terceira métrica que compóe a análise de redes pessoais, e que diz respeito à "situação do indivíduo" (se preso, ou solto) com o qual os entrevistados mantêm contato. Os agentes têm mais interações com pessoas classificadas como presas (indivíduos que cumprem pena, ou trabalham na prisão), do que os internos. Enquanto 28,3\% das interaçôes dos presos se dão com pessoas que estão numa penitenciária, 39,9\% das interações dos agentes se dâo com sujeitos que pertencem ao mundo encarcerado; ou seja, internos ou colegas de profissão (Tabela 3).

Para entender quem é o sujeito, dentro do mundo prisional, com o qual o agente ou o preso interagem, qualificamos o grupo de referência ao qual o alter de cada ego pertence, utilizando as informaçóes dadas pelos entrevistados (Tabela 4). Verificamos, então, que $38,6 \%$ dos agentes prisionais têm como alters os colegas de trabalho, sendo este o maior grupo com o qual eles se relacionam. Os detentos têm uma rede de relacionamentos mais diversa, organizada a partir de três categorias principais: familiares (26\% dos alters), amigos da prisão (22,3\%), e amigos externos ao ambiente prisional (21\%). 
Tabela 3

Natureza das Interaçóes que Configuram as Redes de Relacionamento dos Presos e Agentes Entrevistados

\begin{tabular}{|c|c|c|c|c|c|c|}
\hline \multirow[b]{2}{*}{ Agente prisional } & & & \multicolumn{3}{|c|}{ Esse indivíduo está preso? } & \multirow[b]{2}{*}{ Total } \\
\hline & & & Sim & Náo & Sem informaçáo & \\
\hline & Não & $\mathrm{N}$ & 109 & 243 & 33 & 385 \\
\hline & & $\%$ & $28,3 \%$ & $63,1 \%$ & $8,6 \%$ & $100,0 \%$ \\
\hline & Sim & $\mathrm{N}$ & 89 & 110 & 24 & 223 \\
\hline & & $\%$ & $39,9 \%$ & $49,3 \%$ & $10,8 \%$ & $100,0 \%$ \\
\hline \multirow{2}{*}{\multicolumn{2}{|c|}{$\begin{array}{l}\text { Total } \\
\%\end{array}$}} & $\mathrm{~N}$ & 198 & 353 & 57 & 608 \\
\hline & & $32,6 \%$ & $58,1 \%$ & $9,4 \%$ & $100,0 \%$ & \\
\hline
\end{tabular}

Qui-quadrado:11,181 (0,004)

Fonte: Rede nas prisões da RMBH (2015-2017).

Tabela 4

Grupo ao Qual Pertence o Alter dos Egos Analisados - Redes de Relacionamento dos Presos e Agentes Entrevistados

\begin{tabular}{|c|c|c|c|c|}
\hline \multicolumn{2}{|c|}{ Grupo ao qual pertence o alter } & \multicolumn{2}{|c|}{ Agente } & \multirow{3}{*}{$\begin{array}{l}\text { Total } \\
117 \\
\end{array}$} \\
\hline & & \multirow{2}{*}{$\begin{array}{l}\text { Náo } \\
100\end{array}$} & \multirow{2}{*}{$\begin{array}{l}\text { SIM } \\
17\end{array}$} & \\
\hline Família & $\mathrm{N}$ & & & \\
\hline & $\%$ & $26,0 \%$ & $7,6 \%$ & $19,2 \%$ \\
\hline \multirow[t]{2}{*}{ Amigo/ Conhecido/ Interno } & $\mathrm{N}$ & 86 & 42 & 128 \\
\hline & $\%$ & $22,3 \%$ & $18,8 \%$ & $21,1 \%$ \\
\hline \multirow[t]{2}{*}{ Amigo/ Conhecido/ Externo } & $\mathrm{N}$ & 81 & 28 & 109 \\
\hline & $\%$ & $21,0 \%$ & $12,6 \%$ & $17,9 \%$ \\
\hline \multirow[t]{2}{*}{ Inimigo } & $\mathrm{N}$ & 12 & 3 & 15 \\
\hline & $\%$ & $3,1 \%$ & $1,3 \%$ & $2,5 \%$ \\
\hline \multirow[t]{2}{*}{ Equipe psicossocial } & $\mathrm{N}$ & 58 & 12 & 70 \\
\hline & $\%$ & $15,1 \%$ & $5,4 \%$ & $11,5 \%$ \\
\hline \multirow[t]{2}{*}{ Agentes prisionais } & $\mathrm{N}$ & 11 & 86 & 97 \\
\hline & $\%$ & $2,9 \%$ & $38,6 \%$ & $16,0 \%$ \\
\hline \multirow{2}{*}{$\begin{array}{l}\text { Possui mais de um tipo de } \\
\text { pertencimento }\end{array}$} & $\mathrm{N}$ & 6 & 11 & 17 \\
\hline & $\%$ & $1,6 \%$ & $4,9 \%$ & $2,8 \%$ \\
\hline \multirow[t]{2}{*}{ Sem informação } & $\mathrm{N}$ & 31 & 24 & 55 \\
\hline & $\%$ & $8,1 \%$ & $10,8 \%$ & $9,0 \%$ \\
\hline \multirow{2}{*}{$\begin{array}{l}\text { Total } \\
\%\end{array}$} & $\mathrm{~N}$ & 385 & 223 & 608 \\
\hline & $100,0 \%$ & $100,0 \%$ & $100,0 \%$ & \\
\hline
\end{tabular}

Qui-quadrado: 164,252 (0,000)

Fonte: Rede nas prisões da RMBH (2015-2017). 
A interação mais frequente dos presos foi com a família (26\% das interaçōes), indicando quão vital é a presença dos familiares para a sobrevivência no ambiente prisional (Silvestre, 2012; Godoi, 2017; Martino, 2019). Entre os agentes, a interação mais frequente é com aqueles que compartilham o mesmo destino profissional, como pode ser identificado na seguinte entrevista:

Eu moro sozinho, então eu não tenho tanto contato assim com... Para falar com a família de questóes pessoais mesmo, minhas, náo. Então, é mais no dia a dia mesmo; no serviço, a gente está mais presente com os colegas de trabalho, do que com a própria família (Entrevista 1 - Agente da Jason).

Mais do que a quantidade de contatos, importa a qualidade deles, o que nas redes pessoais pode ser mensurado pela frequência da interação. Esta medida pode variar entre um (o que significa alguém com quem o indivíduo interage pouco) até 100 (alguém com quem o entrevistado tem muito contato). A frequência média de contatos dos agentes prisionais com seus alters é de 13 interaçôes por mês. Quando observamos a mediana no Boxplot $1,{ }^{10}$ verificamos que a frequência da interação com sujeitos que não estáo presos é maior do que com aqueles que estáo (14 versus 18 contatos por mês).

Quando olhamos para os detentos, que têm redes mais amplas e dispersas em três grupos de referência distintos, constatamos que a frequência das interaçóes com outros na mesma situação é muito superior àquela observada com indivíduos que estão fora dos muros prisionais, como familiares. Assim, enquanto a mediana da frequência de interação com sujeitos presos é de 30 contatos por mês (muito superior à frequência de interaçấo dos agentes com qualquer outro alter), com indivíduos que não estáo presos essa frequência é de apenas dois contatos por mês, possivelmente porque tal interação ocorre primordialmente em dias de visita (Boxplot 2).

\section{Boxplot 1}

Frequência Mensal de Contatos de Agentes Prisionais com Sujeitos que Estáo Presos e Soltos

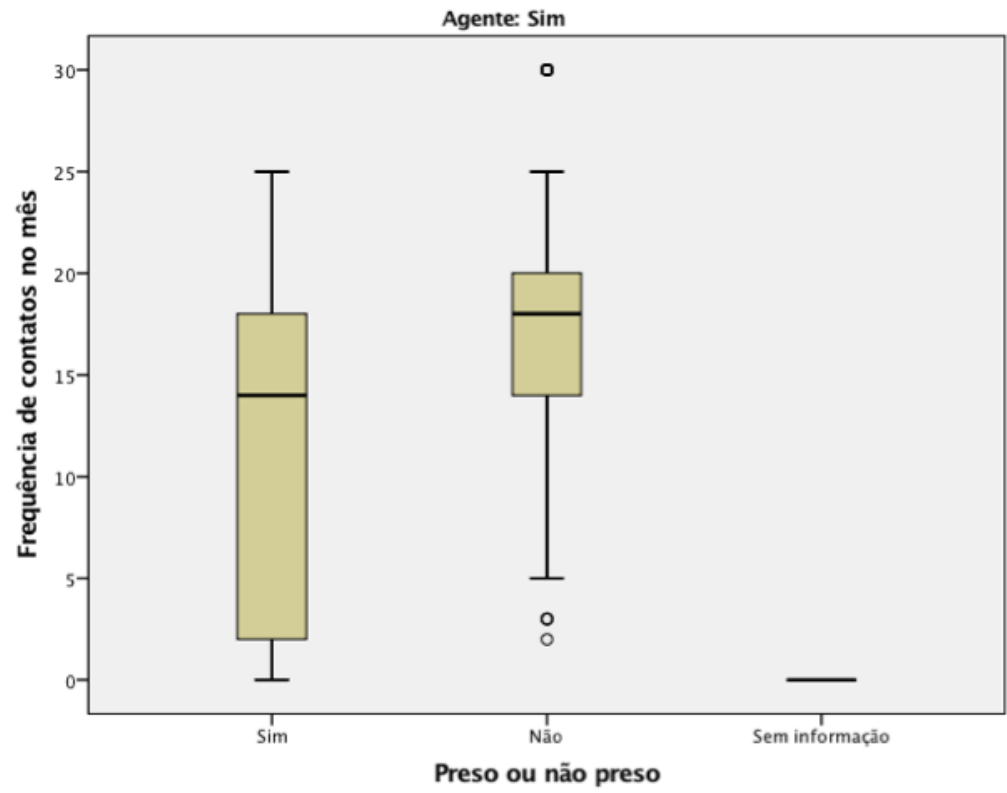

Fonte: Rede nas prisões da RMBH (2015 - 2017). 


\section{Bloxplot 2}

Frequência Mensal de Contatos de Detentos com Sujeitos que Estáo Presos e Soltos

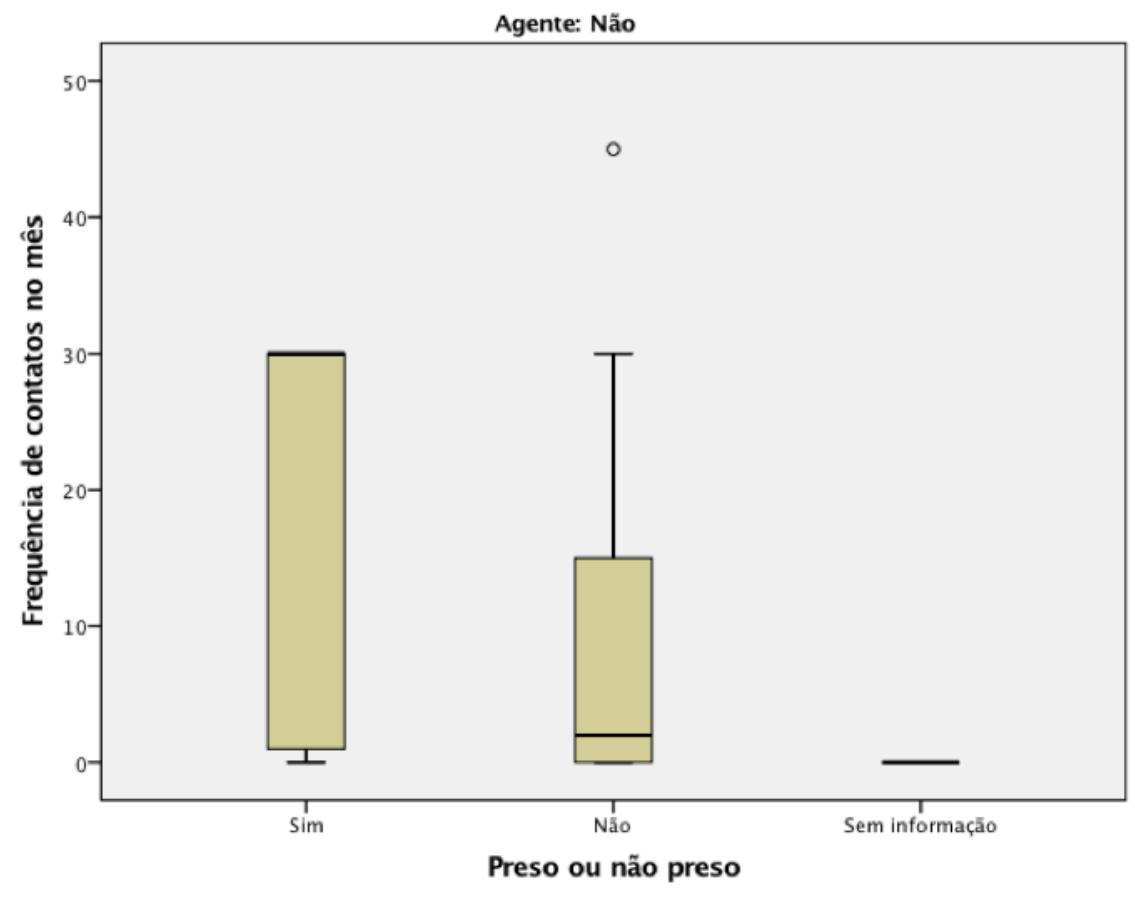

Fonte: Rede nas prisões da RMBH (2015 - 2017).

Como as prisóes mineiras estão superlotadas, apresentando uma taxa de ocupação de 200\% (FBSP, 2018), é natural que os efeitos do aprisionamento nos presos sejam visíveis no contato mais intenso com outros detentos. Já, entre os agentes, apesar de haver, em suas redes, muitos sujeitos na condição de "encarcerados", a possibilidade de saírem da prisão ao final do expediente, leva a que as interaçóes mais frequentes estejam para além dos muros da unidade prisional.

Outras medidas necessárias para o entendimento dos formatos assumidos pelas redes pessoais são a densidade e as distâncias geodésicas: métricas que procuram calcular se os alters de cada ego estabelecem contato entre si ou não, e qual é a distância média entre o ego e os alters, respectivamente (Wasserman e Faust, 1984).

A densidade é um índice que varia entre 0 e 1 , e indica o quão conectados estáo os alters do ego, assumindo o valor zero numa rede totalmente fragmentada e 1 numa rede completamente conectada (Lazega e Higgins, 2014). Os agentes penitenciários possuem redes pessoais mais densas do que os presos (Tabela 5), o que pode ser demonstrado no score de 0,76 para eles versus 0,65 para presos, além do desvio- padrão mais baixo $(0,17$ para os agentes, e 0,22 para os presos), indicando uma menor dispersão dos grafos. ${ }^{11}$ Em conjunto, a média e o desvio- padrão da densidade das redes indicam que os contatos dos agentes são mais entrelaçados entre si, quando se compara a rede deles com a dos indivíduos presos.

A distância geodésica aufere a média das distâncias entre os nós no grafo (Lazega e Higgins, 2014). É uma medida de distância entre dois indivíduos, e que leva em conta quantos indivíduos fazem intermediação entre eles (Merlini, 2014). Na média, as redes dos agentes possuem distância geodésica me- 
Tabela 5

Estatísticas Descritivas das Densidades dos Grafos entre Agentes Penitenciários e Presos

\begin{tabular}{lllll}
\hline Categoria & Número de casos & Média & Mediana & Desvio- Padráo \\
\hline Agentes & 13 & 0,76 & 0,78 & 0,17 \\
\hline Presos & 16 & 0,65 & 0,60 & 0,22 \\
\hline
\end{tabular}

Fonte: Rede nas prisóes da RMBH (2015 - 2017).

Tabela 6

Estatísticas Descritivas das Distâncias Geodésicas dos Grafos entre Agentes Penitenciários e Presos

\begin{tabular}{lllll}
\hline Categoria & Número de casos & Média & Mediana & Desvio-Padráo \\
\hline Agentes & 13 & 1,20 & 1,23 & 0,16 \\
\hline Presos & 16 & 1,35 & 1,30 & 0,28 \\
\hline
\end{tabular}

Fonte: Rede nas prisões da RMBH (2015 - 2017).

nor do que as dos presos (score de 1,20 versus 1,35, respectivamente) e, novamente, menor desvio- padrão $(0,16$ versus 0,28$)$, indicando que os contatos dos agentes estão mais próximos deles, do que as interações que são estabelecidas pelos detentos com os seus alters, as quais estão mais distantes do ego.

O fato de os presos terem mais contatos (em termos de quantidade de alters) possibilita uma maior diversidade de laços (em termos de conexóes com grupos de referência), os quais são, porém, mais distantes em termos de proximidade com o ego (dado pela média das distâncias geodésicas dos grafos). Aparentemente, os presos são mais livres para agir em suas redes, porque estas são menos coesas, posto que os alters estáo menos interligados. $\mathrm{O}$ reverso seria verificado entre os agentes, cujas interaçôes sociais estão mais centradas dentro de grupos muito específicos. Isso pode levar a uma constante vigilância do comportamento, pelo próprio trabalhador, por seus pares e pelos detentos com os quais ele se relaciona; sendo este resultado uma possível mostra do aprisionamento que se institucionaliza como consequência do trabalho custodial (Arnold, 2005; Liebling et al., 2018).

Para testar essa hipótese, as redes egocentradas de todos os entrevistados presos e de todos os agentes foram reconstituídas graficamente. ${ }^{12}$ Todavia, para a adequada interpretação das Figuras 1 e 2, são necessários alguns esclarecimentos sobre o significado de cada componente gráfico. $\mathrm{O}$ tamanho dos vértices é indicativo da quantidade de interações entre o ego (entrevistado) e seus alters. Logo, figuras maiores significam que aquele ego tem uma frequência de relações muito maior com aquele alter, do que com os demais, representados por figuras menores.

Os sujeitos com os quais o ego estabelece interaçôes são representados de forma diferenciada, sendo que o quadrado equivale a um sujeito preso (ou que trabalha na prisão), enquanto o círculo indica indivíduos que não estão presos. Já, os que não têm uma forma definida são os casos sem informação. Os alters se diferenciam, ainda, em termos de cor, conforme o grupo de referência a que pertencem (Quadro 1).

A Figura 1, em razão da profusão de elementos azuis, indica que o mundo dos agentes prisionais está muito conectado aos colegas de profissão. Nota-se, ainda, uma elevada presença de elementos gráficos de cor verde, sinalizando para uma intensa interação com outros presos - o que pode ser interpretado, segundo os nossos entrevistados, a partir de duas chaves diferenciadas: (i) são contatos anteriores à prisão, dado que os agentes prisionais são recrutados nas mesmas classes sociais das quais se originam os detentos - o que também explicaria os quadrados 
Quadro 1

Indicativo de Cores para a Interpretaçáo das Figuras 1 e 2

\begin{tabular}{ll}
\hline Cor & Significado \\
\hline Vermelho & Membros da família \\
\hline Verde & Amigo ou conhecido do mundo interno às prisões \\
\hline Amarelo & amigo/conhecido do mundo externo às prisóes \\
\hline Preto & Inimigo \\
\hline Laranja & Equipe psicossocial \\
\hline Azul & Agente prisional \\
\hline Rosa & Afetos, sem identificação \\
\hline
\end{tabular}

Fonte: Elaboração dos autores.

vermelhos, que representam os familiares presos (Crawley, 2004; Roseira, 2018) ; ou (ii) são contatos estabelecidos no mundo encarcerado, com o objetivo de tornar o trabalho custodial mais eficiente (Liebling et al., 2018; Monteiro e Araújo, 2018).

Quando presos e agentes são amigos de "longa data" - isto é, antes da entrada do detento no presídio -, há uma enorme dificuldade de exercício do trabalho custodial (Nascimento, 2019), sendo necessário, por vezes, um acompanhamento psicológico para que os agentes saibam como lidar com tais situaçóes, como nos explicou um entrevistado :

Porque o sistema prisional é grande, para a gente ser preso basta estar livre, né? No caso do preso que já está no crime e tal, um vizinho meu está lá, ele é... ele foi preso, foi levado lá para... para a cadeia onde que eu estou locado, fazer o quê? Ele me viu, ele sabe que agora eu estou solto. No caso meu aqui, como moro do lado aqui... em um bairro vizinho, fica muito mais fácil da família saber que... né, às vezes estou em um supermercado, às vezes estou em um açougue e tal, "ah aquele ali é agente da cadeia", mas o... o laço da minha família com o laço da família do preso, no meu caso, é... quase que nenhum (Entrevista Agente - Santa Luzia).

$\mathrm{Na}$ tentativa de evitar tais constrangimentos, os agentes relataram que o trabalho nas prisões significa uma tentativa de redução da "diversidade" de indivíduos com os quais mantêm contatos razão pela qual as formas amarelas (amigos fora do ambiente prisional) não são tão frequentes na Figura 1 . De acordo com os entrevistados, relações fora do ambiente prisional devem ater-se à família, que preenche (formas com a cor vermelha) certos espaços das redes de relacionamento dos agentes prisionais. Para alguns, a família é um anteparo indispensável para que o profissional possa suportar as angústias do cárcere, como indicam as citações seguintes:

O meu marido, meu marido, minha irmá. Que... tipo... eles falam que não tem que levar nada para casa, mas não tem como a gente não levar; meu marido que é meu suporte. Chego lá, eu falo tudo que aconteceu no dia, e ele também, né? A gente quer saber o que aconteceu no dia da pessoa. (Entrevista Agente PJMA).

Assim... Eu tento não levar muito, né... tudo o que acontece aqui, para fora... Até mesmo é uma forma de descanso. Eu compartilho com minha esposa, né? Algumas coisas com a minha mãe e... dificilmente com outras. (Entrevista Agente Bicas II).

Portanto, as redes pessoais dos agentes prisionais estão muito centradas em seus colegas de profissão e nos detentos. Porém, em termos de tamanho dos elementos gráficos, as famílias (que são grupos externos à prisão) ganham destaque, espe- 
Figura 1

Representação das Redes Egocentradas dos Agentes Prisionais Entrevistados

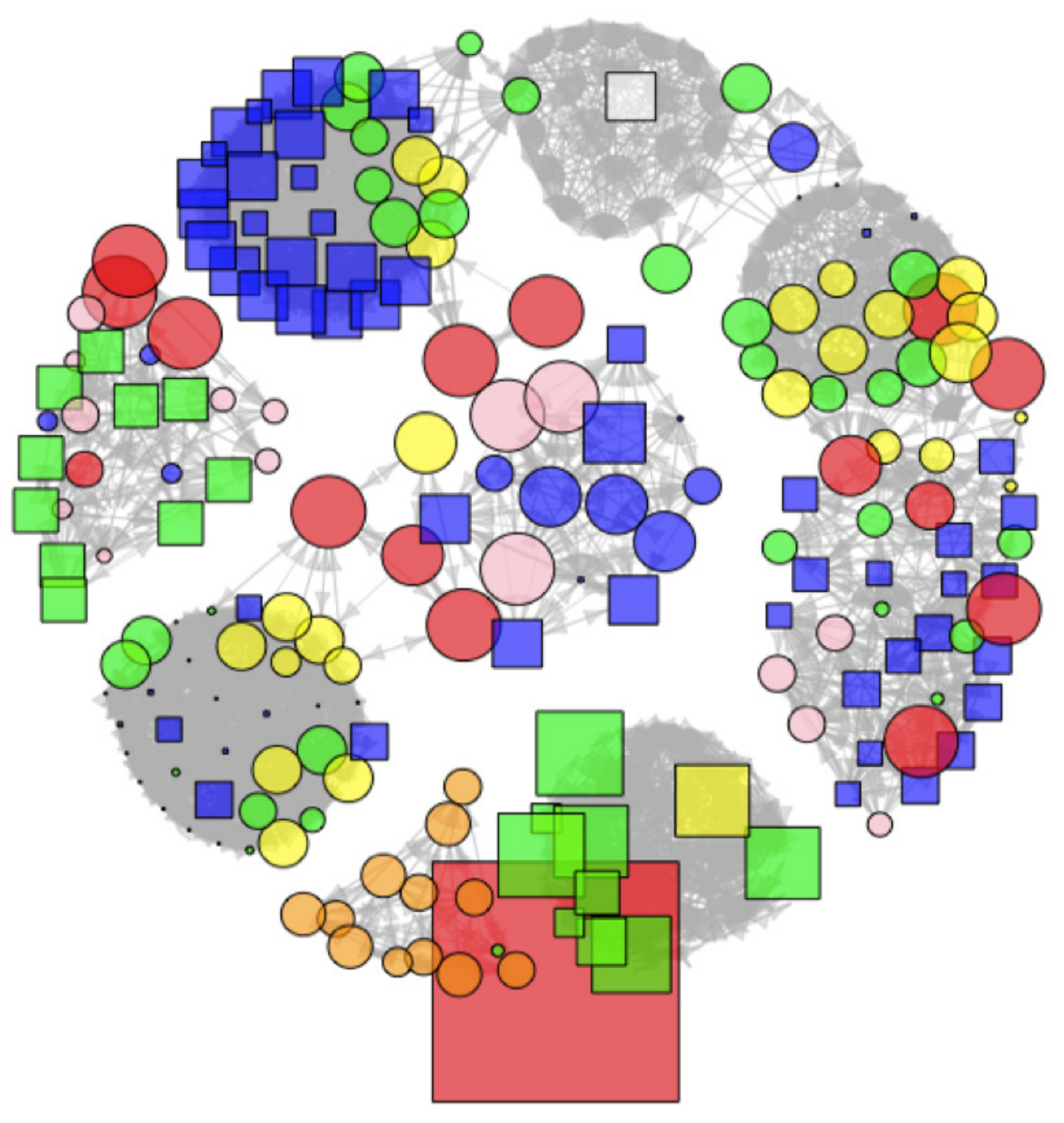

Ver Quadro 1

Fonte: Rede nas prisões da RMBH (2015-2017).

cialmente por cumprirem a função de apoio emocional, indispensável para a garantia da saúde mental dentro da prisão. Ou seja, apesar de os agentes terem suas redes compostas, em boa medida, por colegas de profissão (considerados presos), as interações mais frequentes ocorrem com indivíduos que não pertencem ao mundo prisional; isto é, os familiares (Figura 1). Como os agentes transitam dentro e fora das prisóes, eles são capazes de estabe- lecer mais interaçóes extramuros do que intramuros, ainda que esses contatos estejam centrados em poucos indivíduos.

Ao contrário dos agentes, os presos estabelecem uma miríade de relaçôes com grupos diferenciados, o que se evidencia pela maior diversidade de cores na Figura 2. Inclusive, uma cor que se faz excessivamente presente, em grandes imagens, é a verde, que indica amigos pertencentes ao mundo prisional, 
tanto no formato de quadrados (indivíduos presos), como no formato de círculos (indivíduos soltos). Este desenho pode reforçar a ideia de que a prisão fomenta a organizaçấo de grupos criminosos (Dias, 2017; Godoi, 2017), dado que o enorme tamanho dos quadrados verdes e as conexóes estabelecidas entre eles indicariam as trocas que ocorrem entre os presos, confirmando a frequência dos contatos com outros internos, apresentada no Boxplot 2.

Outra cor que também povoa a Figura 2, mas que está menos presente na Figura 1, é a laranja, que representa os profissionais dos setores psicossociais das prisóes. São eles que desempenham as atividades de aconselhamento social, atendimento psicológico, médico, odontológico, dentre outros (Monteiro e Araújo, 2018). Como tais serviços são disponibilizados apenas aos internos, poucos são os agentes prisionais que estabelecem relaçôes com os mesmos (apenas um caso). Soma-se a isso o fato de que a construção da identidade profissional de agentes e técnicos baseia-se em uma histórica oposição entre estes grupos, em constantes disputas

Figura 2

\section{Representaçáo das Redes Egocentradas dos Presos Entrevistados}

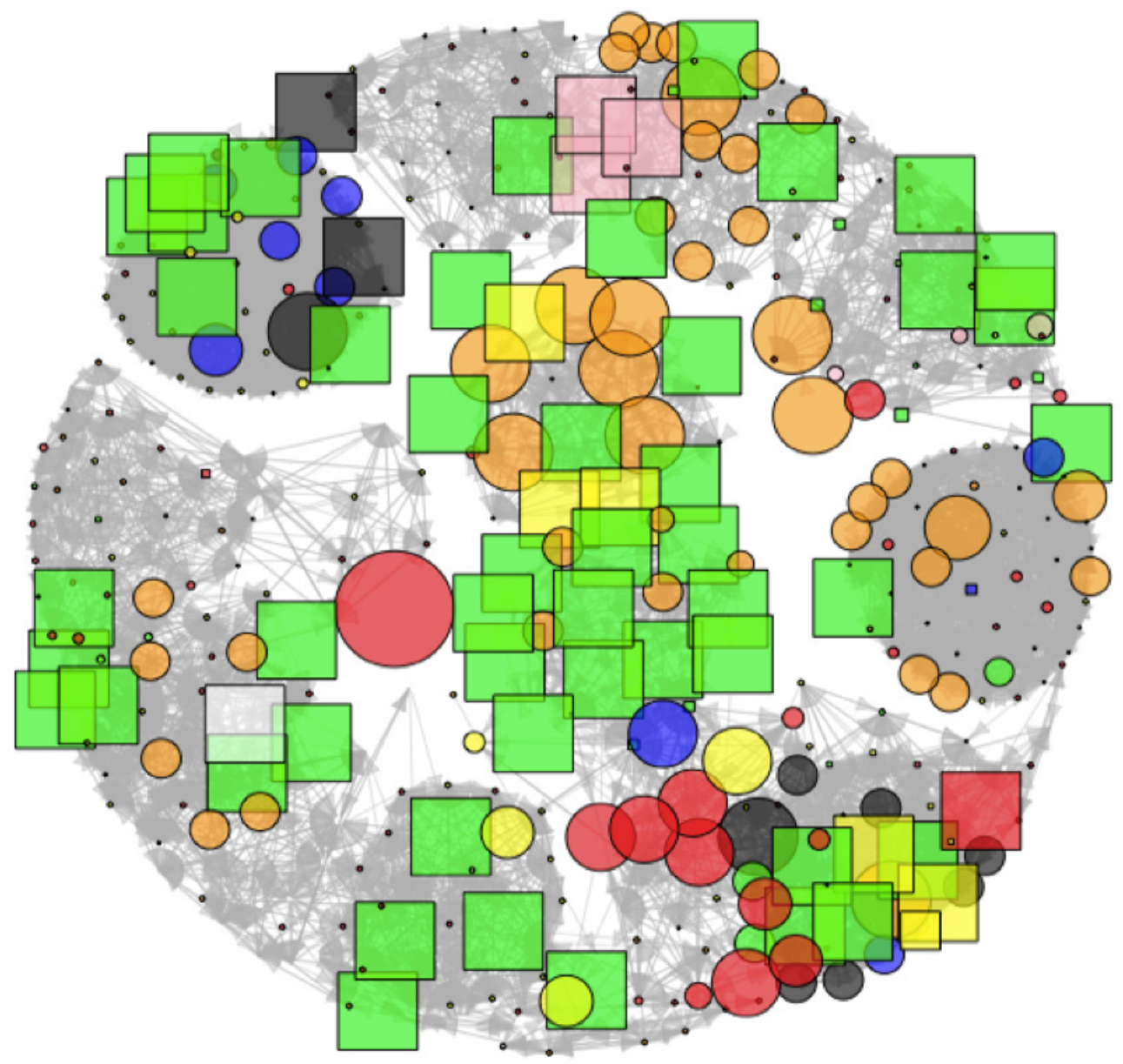

Ver Quadro 1

Fonte: Rede nas prisóes da RMBH (2015-2017). 
(Thompson, 1980), o que contribui para que não exista um relacionamento mais próximo entre eles.

Em suma, os dados coletados com os questionários sociométricos indicam que as ego-networks de agentes e presos são distintas, em termos de sua amplitude, diversidade de grupos de referência a que pertencem os egos, frequência das interaçóes mensais com sujeitos presos e soltos, além de densidade e distância geodésica. Agentes têm redes mais fechadas, com maior participação dos colegas de profissão, ainda que a maior frequência de contatos seja com os familiares que estão fora do ambiente prisional. Além disso, na rede dos agentes há a presença de alguns internos, com os quais eles estabelecem proximidade, provavelmente, para a garantia de informaçóes privilegiadas (Coelho, 2005) ou com os quais já tinham interação antes do trabalho na penitenciária, devido à origem social desse segmento profissional (Moraes, 2005).

Os presos, por sua vez, têm redes de contatos mais ampliadas e menos densas, com alters mais diversificados, em termos de grupos de referência: família, amigos do cárcere ou fora dele, agentes prisionais e servidores do setor psicossocial da unidade. No entanto, a frequência maior de interaçóes é com outros internos, o que pode ser explicado pela superlotação e, talvez, pela maior expansão das redes de crime organizado dentro das prisóes mineiras (Oliveira, 2018). ${ }^{13}$

Diante desses resultados, a pergunta que se apresenta é: em que medida a menor amplitude e a maior densidade das redes pessoais de agentes prisionais (em comparação com as dos presos) é decorrência do exercício do trabalho custodial?

\section{Efeitos do trabalho custodial: aprisionamento dos agentes em suas redes?}

De acordo com as discussóes realizadas nas seçóes anteriores, é possível afirmar que a categoria aprisionamento possui duas dimensóes. Por um lado, ela significa a absorção da rotina prisional, tornando o agente essencialmente próximo ao preso, em termos de linguajar e padrão de comportamento; sendo este um estratagema utilizado por esse profissional para a produção de identificação com os inter- nos e, por conseguinte, a manutenção do equilíbrio nas prisōes (Freitas, 1985; Sykes, 1965; Monteiro e Araújo, 2018). Por outro lado, o aprisionamento significa escassez de relaçóes positivas com pessoas fora das prisóes - agentes e presos - (Clemmer, 1940; Clemmer, 1950), seja por medo de que o sujeito que se aproxima possa ser um potencial agressor (Moraes, 2013), seja por temor de que o interlocutor náo compreenda o papel do agente prisional, muitas vezes entendido como táo criminoso quanto o dos presos (Lourenço, 2010). A combinação dessas duas dimensóes tornaria o mundo dos agentes centrado em seus colegas e em outros presos, diminuindo a diversidade dos sujeitos com os quais os agentes se relacionam (Arnold, 2005)..$^{14}$

A análise de redes egocentradas demonstrou, em parte, o referido argumento. Apesar de os colegas de profissáo serem a maioria dos alters dos agentes entrevistados (o que seria um indicativo do aprisionamento), em termos de frequência de contatos mensais, os familiares são os sujeitos com os quais os trabalhadores custodiais mais interagem. Logo, há certo aprisionamento, mas há também alguma abertura da rede. Na presente seção, apresentamos as entrevistas realizadas nas setes unidades prisionais, com 13 agentes penitenciários, na tentativa de entender como e se o trabalho custodial interfere em suas redes de relacionamento, levando ao aprisionamento.

Para a efetividade do seu trabalho, o agente tem necessidade do preso (Lourenço, 2010). Por isso, ele busca manter um bom relacionamento com o interno, garantindo a sua cooperação nos momentos em que a ordem na prisão está em xeque (Monteiro e Araújo, 2018). Entretanto, é preciso também manter certa "distância", para garantir a hierarquia e, sobretudo, a diferença entre os dois grupos (Paixão e Coelho, 1984). Em resumo, o "agente penitenciário se digladia o tempo inteiro com a identificação e a proximidade com o preso, que, para ele, aumenta os riscos de sua 'contaminação' moral pela massa carcerária” (Moraes, 2013, p. 141).

$\mathrm{Na}$ tentativa de evitar o "perigo da contaminação" (Freitas, 1985), o agente deve estar em constante estado de alerta consigo próprio, vigiando seu linguajar e padróes de comportamento que possam indicar qualquer proximidade com a massa carce- 
rária (Moraes, 2005). O constante estado de alerta, decorrente da tríade "vigiar, desconfiar e controlar", principal programa de ação dessa categoria profissional (Arnold, 2008), impede interaçóes com desconhecidos, por receio de que elas possam se tornar uma ameaça (Arnold, 2005; Bandeira e Batista, 2009; Crawley, 2004; Morris e Morris, 1962; Steiner e Wooldredge, 2016).

Os agentes entrevistados destacaram que, em virtude do trabalho custodial e da clientela com a qual precisam lidar, é imprescindível que selecionem melhor as suas amizades, com temor de que elas possam estar relacionadas a indivíduos que cumprem pena e, dessa maneira, ocasionar-lhes problemas para o exercício de sua função. Ao adotar tal atitude diante de sujeitos com os quais interage, o agente faz com que sua rede seja mais restrita, posto que mais seletiva, em termos de pessoas específicas com as quais ele divide as angústias do dia a dia.

O temor de que aqueles indivíduos, considerados "perigosos" em potencial, estejam mais próximos do que os agentes penitenciários gostariam, faz com que estes profissionais escolham cuidadosamente os contatos de sua rede e, muitas vezes, restrinjam suas interaçóes às pessoas do ambiente prisional (Liebling et al., 2018). Mesmo neste caso, os olhos e os ouvidos extremamente atentos devem estar em funcionamento, para evitar qualquer risco, como nos explicou um entrevistado:

A cautela, atenção... ela tem que existir, do período que eu saio da minha casa até a chegada ao meu trabalho. E assim, da saída do meu trabalho até chegar à minha casa. Eu, pelo menos, saio de casa dessa forma. Mas, se tratando dentro da unidade prisional, eu acho que a todo o momento você tem que estar atento para tudo que está acontecendo... porque o guarda, ali, ele não trabalha só com a arma na cintura; ele trabalha com os olhos e com ouvido. Isso, para mim, é a principal arma que eu uso a trabalho, né? Eu estou conversando com vocês aqui, mas eu estou prestando atenção no que está acontecendo lá no pátio, né? Eu estou escutando a movimentação dos presos lá; então, essa, para mim, é a maior cautela que eu tenho que ter, né? Então, assim, de tudo, é isso, em geral, pro- priamente o que eu posso dizer; é isso, mas você tem que estar atento a tudo. No caso aí, vamos dizer de... de postos, setores, é... no caso da escolta, eu faço parte, né, dessa... dessa escolta aí, eu sou um dos agentes de apoio dessa escolta... Sair com preso sempre é um risco, tá? (Entrevista Agente 03 - Presídio de Santa Luzia).

A maior ameaça é a presença de detentos nas redes dos agentes, em virtude de acordos ou facilitação de mercadorias proibidas - o que Sykes (1965) denominou de "corrupção da autoridade". Nossos entrevistados nomeiam tais práticas de acordos de cooperação mútua, ou favores que podem ser estabelecidos no curso de interaçóes cotidianas nas unidades prisionais. Tais acordos geram comprometimentos e vínculos extremamente fortes entre as partes envolvidas (Cloward, 1968; Freitas, 1985; Hepburn e Crepin, 1984; Sykes, 1965). Os agentes que optam por esse caminho podem ser cobrados pelos presos, pelas dívidas contraídas e, dependendo da situação, podem correr sérios riscos de morte, como relata outro agente prisional ouvido na pesquisa:

Mas, a possibilidade de dívida com o preso, ela só é gerada a partir do momento que você se envolve com o preso; se você não se envolve com o preso, você não... A partir do momento que você tem uma relação de negócios com o preso, aí você adquire dívidas; se você não fizer nenhum tipo de negócio com o preso... e o preso... aqui dentro, é proibido qualquer tipo de comércio, dentro de unidade prisional. Se você faz negócio com o preso, a possibilidade... probabilidade de ser um negócio lícito é quase zero. Se você adquirir uma dívida, é porque você fez um negócio, e o negócio provavelmente não é lícito; já está errado (Entrevista Agente - Bicas II).

As maiores tensóes, nas redes de relacionamento dos agentes, emergem quando, nas unidades prisionais, há suspeita de que algum colega de trabalho esteja se corrompendo para facilitar a entrada de drogas, celulares ou outros objetos proibidos pela administração dessas unidades. O clima de suspeição no grupo gera distanciamentos entre os pares e esgarça os laços de confiança estabelecidos 
entre eles. Para náo ser rotulado como um agente cuja autoridade foi corrompida a partir de contatos com os presos (Sykes, 1965), muitos entrevistados disseram evitar ao máximo a interação com os detentos e seus familiares:

Já, nós tivemos um funcionário que foi desligado aqui da unidade; já algum tempo que a gente recebeu informaçóes que ele estava trazendo objetos indevidos para a unidade... [...] Até então, nós, agentes penitenciários, ficamos assim encucados, porque... estavam surgindo muitos celulares, dois, três... então, começou a surgir dúvida da índole do nosso próprio companheiro de trabalho, porque não tem como entrar assim nessa facilidade. Então, se estava ocorrendo nessa facilidade... então, alguém... $\mathrm{Na}$ mentalidade nossa, alguém estava facilitando isso; mas então, essa última apreensão que a gente fez desses quarenta celulares, foram quarenta celulares, setenta chips, serra, broca... [...] A partir do momento que passa a ter essas grandes apreensóes... em qualquer unidade prisional, é... é normal; em qualquer unidade prisional, a partir do momento que começa a acontecer grandes apreensôes, apreensão de celulares, de drogas, querendo ou não, deixa no ar aquele ar de desconfiança: "Olha, alguém... algum funcionário está saindo...”; não existe só o agente penitenciário; como tem outros funcionários, é... da área da saúde, a cozinha... em si (Entrevista Agente Jason).

Essa preocupação com a segurança pessoal, tanto dentro quanto fora das prisóes, tem como externalidade a redução considerável do tamanho da rede dos agentes, e o aumento da frequência de contatos com indivíduos específicos, considerados “confiáveis". Ela produz também outros impactos comportamentais, como evitar frequentar determinados lugares públicos, sair à noite, e reproduzir o mesmo caminho ao sair da unidade prisional onde se trabalha (Lourenço, 2010; Roseira, 2018).

Para os entrevistados, o maior efeito do trabalho custodial seria o sentimento de estar "recluso", mesmo após o fim do expediente, devido à restrição a uma rede de contatos reduzida, da qual se deve desconfiar sempre, gerando neles um enorme desgaste físico e mental - como nos explicou uma agente prisional feminina:

Aí, o que a gente tem que fazer, sair daqui, né? Assim, ir embora, pegar esse trânsito ruim que a gente tem; aí, você chega à sua casa, você toma um banho, você vai fazer alguma coisa, você vai fazer outra, você vai dormir lá pelas onze horas, meia noite; aí, cinco horas da manhã, você tem que estar aqui de novo. Então, esse tempinho que você tem para dormir, você não desliga, você já acorda cansada, entendeu? (Entrevista Agente 02 - PIEP).

Esse sentimento de desconfiança constante - de tudo e de todos - é potencializado, na visão dos entrevistados, pela imagem que eles julgam ter diante da sociedade como um todo: a de serem tão "criminosos" quanto os detentos que eles guardam. Tal percepção pode contribuir para uma atitude mais distante, isolada e defensiva, em relação àqueles que náo conhecem a realidade da vida e do trabalho nas prisóes:

Nós, agente penitenciários, nós nos sentimos um pouco excluídos da sociedade. [...] Não sei se é uma falha devido ao próprio sistema... da própria secretaria, do próprio estado, ou uma... uma... má divulgação, sabe? Eu acho que a sociedade deveria estar mais integrada do assunto. $\mathrm{O}$ que é um agente penitenciário? Qual que é a função do agente penitenciário? Porque muitos, na cabeça da sociedade, o trabalho do agente penitenciário é bater no preso, é espancar o preso... não é esse o nosso trabalho. (Entrevista Agente Jason).

Para outros agentes prisionais, a constante vigilância de suas redes de contatos faz com que eles se sintam aprisionados, obrigados a vigiar, controlar e desconfiar daqueles com os quais estabelecem qualquer relação social. Neste diapasáo, suas redes não podem ser amplas como as dos presos, que contam com interaçôes múltiplas, tanto com quem está na prisão, como com quem está fora dela. Todavia, há certa abertura, nas redes dos agentes, para um grupo 
social que parece ser confiável, apesar dos pesares: a família. Este é o grupo com o qual os agentes prisionais estabelecem interações muito frequentes, ainda que ele seja minoria nas redes pessoais analisadas.

Em resumo, os depoimentos analisados, na presente seção, indicam que o exercício da atividade custodial tem uma série de efeitos sobre o comportamento dos agentes prisionais, reverberando na conformação de suas redes pessoais. Abrir a rede pessoal e/ou fechá-la, tanto em termos da quantidade e diversidade de indivíduos, como em termos da intensidade dos contatos, são estratégias de adaptação diferenciadas, de que os agentes prisionais lançam mão para a garantia de uma maior segurança e efetividade no desempenho de suas atividades custodiais.

\section{Consideraçóes finais}

A proposta deste artigo foi entender a configuração das redes pessoais dos agentes prisionais, a partir dos dados coletados junto a detentos e funcionários de sete unidades penitenciárias da Região Metropolitana de Belo Horizonte, entre 2015 e 2017. Para melhor compreensão do nosso problema de pesquisa, partimos de estudos recentes sobre essa categoria profissional, os quais destacam como o trabalho de custódia desempenhado pelos agentes penitenciários afeta diretamente suas vidas profissional e pessoal.

Em seguida, sublinhamos como, em âmbito nacional, algumas pesquisas têm chamado atenção para as mudanças ocorridas nas penitenciárias, com o crescimento exponencial da população prisional. As alterações verificadas nos ambientes custodiais, em razão da superlotação e do crescimento das redes de crime organizado, têm dificultado sobremaneira as atividades rotineiras dos agentes. Isso faz com que eles tenham maior temor do "perigo da contaminação” e, por conseguinte, estejam em constante "estado de alerta", o que reverbera em uma menor rede de contatos.

$\mathrm{Na}$ parte analítica, procuramos entender se existe e, em caso afirmativo, como se dá a restrição dos contatos dos agentes prisionais a sujeitos específicos do ambiente penitenciário. Para tanto, comparamos as estruturas e os componentes das redes pessoais de 13 agentes penitenciários com os de 16 presos em unidades penitenciárias da $\mathrm{RMBH}$, entre os anos de 2015 e 2017.

Utilizando as métricas das redes pessoais, constatamos que os presos interagem com uma quantidade maior de indivíduos; sendo que a frequência dessa interação é maior com os sujeitos presos, do que com aqueles que estão livres. Já, os agentes têm redes mais restritas, sendo que mais de $1 / 3$ de seus contatos são outros colegas de profissão, qualificados pelos entrevistados como "sujeitos aprisionados". Porém, em termos de frequência mensal de contatos, a família é a campeã, sendo o principal apoio emocional do agente. Por fim, a grande presença de internos nas redes dos agentes indica que o mundo prisional está em suas vidas, para além do ambiente de trabalho, reforçando a lembrança de que esses profissionais transitam entre dois mundos: de um lado, o mundo interior das prisóes (vida profissional) e, de outro, o mundo exterior (vida privada).

Por fim, convém salientar que os agentes não são cativos do mundo prisional, mas que, em razáo do papel desempenhado, desenvolvem um compromisso de zelar pela manutenção da ordem nesse mundo. Tal papel parece se cristalizar em seu modo de vida, a partir do constante emprego da tríade "vigiar, desconfiar e controlar", em seu cotidiano. Com isso, eles acabam se tornando reféns do ambiente prisional; ou seja, acabam aprisionados, mesmo quando estão fora das prisôes, posto que convivem primordialmente com sujeitos que pertencem àquele mundo.

\section{Notas}

1 Termo cunhado por Goffman (1997), para se referir ao processo pelo qual passam os internos ao ingressarem nas "instituições totais", dentre as quais, a prisão. $\mathrm{Na}$ "mortificação do eu", os novatos são submetidos a rebaixamentos, degradaçóes, humilhaçóes e profanaçôes do seu "eu". São impedidos de contatos com suas famílias, como também de saídas temporárias; devem entregar seus objetos pessoais, e são incluídos na vida institucional a partir da definição de um número que os caracteriza. Todos esses procedimentos têm como objetivo "mutilar" a personalidade anterior desses indivíduos, fazendo com que eles assumam tão somente a identidade institucional. 
2 Termo cunhado por Sykes (1965), para se referir a um conjunto de privaçóes pelas quais passam os cativos no interior das prisóes; quais sejam: a privação de liberdade, a privação de bens e serviços, a privação de relaçóes heterossexuais, a privação de autonomia e a privação de segurança.

3 Clemmer (1950) afirma que "todo homem que entra numa prisão experimenta a 'prisonizaçáo' em alguma extensão". Nesse contexto, os fatores que podem intensificar o processo de prisonização são: (1) pena longa, (2) personalidade instável, (3) escassez de relaçóes positivas com pessoas fora das prisōes, (4) prontidão e capacidade para se integrar em um grupo prisional primário, com aceitação cega dos dogmas e costumes desse coletivo - o que leva a uma enorme solidariedade com pessoas em situação semelhante -, e, por fim, (5) prontidáo para participar de jogos de azar e de comportamento sexual anormal.

4 A síndrome de burnout ocorre em razão do acúmulo excessivo de estresse, cansaço e pressão, em trabalhadores que possuem atividades ocupacionais repetitivas e desgastantes. Para uma análise pormenorizada sobre os efeitos dessa síndrome, ver Schaufeli e Peeters (2000).

5 As negociaçôes entre agentes penitenciários e presos podem acontecer da seguinte forma: por exemplo, o agente negocia com o preso a "oferta" de que ignorará as transgressóes secundárias que surgirem no dia a dia, e também de que tais informações não serão repassadas ao diretor, para que não ocorra a punição do infrator. Eles se acomodam e tornam-se menos vigilantes em relação às infraçóes. Os presos, por sua vez, devem cooperar com o trabalho dos agentes, impedindo a eclosão de brigas, motins ou rebelióes. Ou seja, instauram-se "acordos tácitos" para a manutenção da imagem do status quo prisional (Freitas, 1985).

6 Para os agentes penitenciários, o silêncio nas prisóes é indicativo de problemas ou de situaçốes graves que possam advir, ao passo que o "barulho" nos pavilhōes faz parte da rotina da vida prisional (Moraes, 2005).

7 Entre 1999 e 2016, a população prisional brasileira passou de 194.100 para 726.712 presos. Deste total, 240.061 estáo encarcerados no Estado de São Paulo (a maior população prisional do país), 68.354 no Estado de Minas Gerais, e 51.700 no Estado do Paraná, segunda e terceira maiores populaçóes prisionais do país, respectivamente (Depen, 2017).

8 Entre os agentes entrevistados, três eram mulheres e dez eram homens. Entre os presos entrevistados, um era transexual, cinco eram mulheres e dez eram homens.
9 O "código cativo", aquele que é construído pelos próprios presos, a partir de sua interaçâo contínua na prisão, possui regras, normas e padróes de comportamento próprios da "sociedade dos cativos"; ou seja, ele regula o mundo dos internos nas prisóes (Sykes, 1965). No entanto, alguns autores têm apontado que o "código cativo" náo é o único existente no mundo prisional, visto que os guardas também possuem um "código" interno, que regula os seus comportamentos em relação aos presos e entre eles próprios (Kauffman, 1981). Ou seja, existem dois ordenamentos informais de regulação do comportamento de cativos e custodiadores no mundo social das prisóes, para além do regulamento formal que estabelece a divisáo de papéis.

10 O Boxplot é um gráfico que resume as estatísticas descritivas principais de um fenômeno. Seu limite inferior é o valor mínimo da distribuição, enquanto o último asterisco representa o maior valor em termos de quantidade de interações que um ego possui com outros alters. A vantagem desse gráfico é o desenho de uma caixa que engloba do primeiro ao terceiro quartil, além de uma linha no meio, indicando a posição da mediana.

11 O desvio-padrão é uma medida de dispersão. Ele indica a capacidade da média em refletir os dados do grupo estudado. Um fenômeno com uma distribuição sem extremos (ou seja, valores muito elevados ou muito baixos) é aquele que tem média igual ao desvio- padrão. Assim, valores de desvio-padrão muito elevados indicam que a média não é uma boa medida do que acontece dentro do grupo estudado.

12 As redes apresentadas não configuram redes completas, sendo apenas a agregação de todas as redes egocentradas construídas com o objetivo de facilitar a análise visual das estruturas relacionais. A construção de uma rede completa dos presos e agentes não é possível, no contexto do presente trabalho, visto que nấo há correspondência entre os nomes dos alters citados: alguns foram mencionados de acordo com seu parentesco, outros por apelido, outros pelo primeiro nome, etc.

13 Um ponto que, talvez, mereça uma análise mais aprofundada reside em investigar em que medida os presos têm redes mais amplas que os agentes, em razão de sua participação no crime organizado que, muitas vezes, conecta o sujeito a outros indivíduos fora da prisão algo que não ocorre com os agentes, que mantêm suas interaçóes restritas a sujeitos com a mesma profissão.

14 É bom destacar que a análise de redes não permite compreender diretamente a primeira dimensão do efeito da prisionização; qual seja, a absorção da lin- 
guagem e dos trejeitos dos detentos. Apreende-se, assim, esse efeito indiretamente, a partir da restrição da rede de contatos a indivíduos que compartilham com o entrevistado o mesmo destino.

\section{BIBLIOGRAFIA}

AKERS, Ronald L.; HAYNER, Norman S.; GRUNINGER, Werner. (1977), Prisonization in Five Countries Type of Prison and Inmate Characteristics. Criminology, 14, 4: 527-554.

ARNOLD, Helen. (2008), The experience of prison officer training. In: Bennet, Jamie; Crewe, Ben; Wahidin, Azrini. Understanding Prison Staff. Nova York: Routledge.

ARNOLD, Helen. (2005), The effects of prison work. In: Liebling, Alison; Maruna, Shad. The effects of imprisonment. Nova York: Routledge. ARNOLD, Helen. (2016), The prison officer. In: Bennet, Jamie; Crewe, Ben; Jewkes, Yvone. Handbook on Prisons. Nova York: Routledge.

BANDEIRA, Lourdes; BATISTA, Analia Soria. (2009), Trajetórias Profissionais e carreira dos agentes penitenciários: Distrito Federal e Goiás. In: Santos, José Vicente Tavares (org). Subsídios para construção de um novo fazer segurança pública. Brasília: SENASP.

BEZERRA, Cláudia de Magalhães; ASSIS, Simone Gonçalves de; CONSTANTINO, Patricia. (2016), Sofrimento psíquico e estresse no trabalho de agentes penitenciários: uma revisão da literatura. Ciência e Saúde Coletiva, 21: 2135-2146.

CLAUS, Waldemar. (2012), Agentes penitenciários: un estado del arte. VII Jornadas de Sociología. Departamento de Sociología de la Facultad de Humanidades y Ciencias de la Educación, La Plata. Disponível em: https:// www.aacademica.org/000-097/388.pdf, último acesso em 15 de julho de 2019.

CLEMMER, Donald. (1950), Observations on imprisonment as a source of criminality. Journal of Criminal Law and Criminology, 41: 311-319.

CLEMMER, Donald. (1940), The Prison Community. Nova York: Rinehart and Co.
CLOWARD, Richard. (1968), Social Control in the Prison. In: Hazelrigg, Loius. Prison within society. A reader in penology. Nova York: Doubleday.

COELHO, Edmundo Campos. (2005), A Oficina do Diabo e outros estudos sobre criminalidade. Rio de Janeiro: Record.

CRAWLEY, Elaine M. (2004), Doing prison work: the public and private lives of prison officers. Nova York: Routledge.

CRAWLEY, Elaine; CRAWLEY, Peter. (2008), Understanding Prison Officers: culture, cohesion and conflict. In: Bennet, Jamie; Crewe, Ben; Wahidin, Azrini. Understanding Prison Staff. Nova York: Routledge.

DARKE, Sacha; KARAM, Maria Lucía. (2016), Latin American prisons. In: Handbook on prisons. Nova York: Routledge. p. 460-474.

DIAS, Camila Caldeira Nunes. (2017), Encarceramento, seletividade e opressão: a "crise carcerária” como projeto político. Análise, 28: 3-30.

DOWDEN, Craig; TELLIER, Claude. (2004), Predicting work-related stress in correctional officers: A meta-analysis. Journal of Criminal Justice, 32, 1: 31-47.

DUFFEE, David. (1974), The correction officer subculture and organizational change. Journal of research in crime and delinquency, 11, 2: 155-172.

FBSP. (2018), Anuário Brasileiro de Segurança Pública. São Paulo: FBSP.

FREITAS, Renan S. (1985), Reversóes hierárquicas e eclosão de conflitos em prisões. Revista de Administração Pública, 19, 4: 27-37.

GODOI, Rafael. (2017), Fluxos em cadeia: as prisões em São Paulo na virada dos tempos. São Paulo: Boitempo Editorial.

GOFFMAN, Erving. (2007), Manicômios, prisóes e conventos. São Paulo: Perspectiva.

HAWKINS, Gordon. (1976), The prison: Policy and practice. Chicago: University of Chicago Press.

HEPBURN, John R. (1989), Prison guards as agents of social control. In: The American Prison. Boston: Springer p. 191-206.

HEPBURN, John R. (1985), The exercise of power in coercive organizations: A study of prison guards. Criminology, 23, 1: 145-164.

HEPBURN, John R.; ALBONETTI, Celesta. 
(1980), Role conflict in correctional institutions. Criminology, 17, 4: 445-460.

HEPBURN, John R.; CREPIN, Ann E. (1984), Relationship strategies in a coercive institution: a study of dependence among prison guards. Journal of Social and Personal Relationships, 1, 2: 139-157.

INFOPEN. (2017), Levantamento Nacional de Informações Penitenciárias 2016. Brasília: Depen. Disponível em: http://depen.gov.br/ Depen/noticias-1/noticias/infopen-levantamento-nacional-de-informacoes-penitenciarias-2016/relatorio_2016_22111.pdf, último acesso em 15 de julho de 2019.

KAUFFMAN, Kelsey. (1981), Prison officers' attitudes and perceptions of attitudes: A case of pluralistic ignorance. Journal of Research in Crime and Delinquency, 18, 2: 272-294.

KING, Sue. (2009), Reconciling custodial and human service work: The complex role of the prison officer. Current Issues in Criminal Justice, 21: 257-277.

LAZEGA, Emmanuel; HIGGINS, Silvio Salej. (2014), Redes sociais e estruturas relacionais. Belo Horizonte: Fino Traço.

LIEBLING, Alison. (2000), Prison officers, policing and the use of discretion. Theoretical Criminology, 4, 3: 333-357.

LIEBLING, Alison; KANT, Deborah; ARNOLD, Helen. (2018), The Two Cultures: Correctional Officers and Key Differences in Institutional Climate. In: Wolldredge, John; Smith, Paula. The Oxford Handbook of Prisons and Imprisonment. Londres: Oxford University Press.

LIEBLING, Alison; PRICE, David, SHEFER, Guy. (2011), The Prison Officer. Nova York: Willian Publishing.

LOMBARDO, Lucien X. (1989), Guards Imprisoned: Correctional Officers at Work. Nova York: Routledge.

LOURENÇO, Luiz Cláudio. (2010), Batendo a tranca: Impactos do encarceramento em agentes penitenciários da Região Metropolitana de Belo Horizonte. Dilemas: Revista de Estudos de Conflito e Controle Social, 3, 10: 11-31.

LOURENÇO, Luiz Claudio; ALVAREZ, Marcos César. (2017), Estudos sobre prisão: um balan- ço do estado da arte nas Ciências Sociais nos últimos vinte anos no Brasil (1997-2017). Revista Brasileira de Informação Bibliográfica em Ciências Sociais - BIB, São Paulo, 84, 2: 1-9.

MARQUART, James W. (1986), Prison guards and the use of physical coercion as a mechanism of prisoner control. Criminology, 24, 2: 347-366.

MARQUES, Eduardo et al. (2007), Redes pessoais e pobreza em Sáo Paulo. In: O uso das redes sociais nas ciências humanas. Florianópolis: Ed. da UFSC.

MARQUES, Eduardo; BICHIR, Renata. (2011), Redes de apoio social no Rio de Janeiro e em São Paulo. Novos Estudos-Cebrap, 90: 65-83.

MARTINO, Natália. (2009), Se você não tem família, fica esquecida aqui dentro": uma análise dos cruzamentos entre as redes familiares e as redes prisionais de mulheres encarceradas. Dissertação de Mestrado em Sociologia. Belo Horizonte: Universidade Federal de Minas Gerais.

MERLINI, Sara. (2014), Comunidades pessoais de jovens que transgridem: ego-redes especializadas e circunscritas. Redes. Revista hispana para el análisis de redes sociales, 25, 1: 125152.

MONTEIRO, Rodrigo Padrini; ARAÚJO, José Newton Garcia. (2018), Manicômio judiciário e agentes penitenciários: entre reprimir e cuidar. Psicologia: Ciência e Profissão, 38: 144158.

MORAES, Pedro Bodê. (2013), A identidade e o papel de agentes penitenciários. Tempo Social: Revista de Sociologia da USP, 25, 1: 131-147.

MORAES, Pedro Bodê. (2005), Punição, encarceramento e construção de identidade profissional entre agentes penitenciários. Sáo Paulo: IBCCRIM.

MORRIS, Terence; MORRIS, Pauline. (1962), The experience of imprisonment. The British Journal of Criminology, 2, 4: 337-360.

NASCIMENTO, Vagner Ferreira et al. (2019), Acesso a informaçóes sobre substâncias psicoativas e o consumo por agentes prisionais. Enfermería actual de Costa Rica, n. 36.

OLIVEIRA, Victor Neiva. (2018), Mudanças na administração prisional: Os agentes penitenciários e a construção da ordem nas prisóes de 
Minas Gerais. Dilemas-Revista de Estudos de Conflito e Controle Social, 11, 3: 412-434.

OLIVEIRA, Victor Neiva; RIBEIRO, Ludmila Mendonça; BASTOS, Luiza Meira. (2015), Os agentes penitenciários em Minas Gerais: Quem são e como percebem a sua atividade. Sistema Penal e Violência, 7, 2: 176-192.

PAIXÃO, Antônio Luiz; COELHO, Edmundo Campos. (1984), Caracterização da População Prisional em Minas Gerais e Rio de Janeiro. Belo Horizonte: Fundação João Pinheiro.

ROSEIRA, Ana Pereira. (2018), A Porta da Prisão: uma história dos meios de segurança e coerção penal na perspectiva dos guardas prisionais portugueses (1974-2014). Tese de Doutorado. Coimbra: Faculdade de Letras da Universidade de Coimbra.

SCHAUFELI, Wilmar B.; PEETERS, Maria CW. (2000), Job stress and burnout among correctional officers: A literature review. International Journal of Stress Management, 7, 1: 19-48.

SILVESTRE, Giane. (2012). Dias de visita: uma sociologia da punição e das prisóes. São Paulo: Alameda, 2012.

STEINER, Benjamin; WOOLDREDGE, John. (2015), Individual and environmental sources of work stress among prison officers. Criminal Justice and Behavior, 42, 8: 800-818.

SYKES, Gresham M.; MESSINGER, Sheldon L. (1960), The inmate social system. In: Theoretical studies in social organization of the prison. Nova York: Social Science Research Council. p. 5-19

SYKES, Gresham. (1965), The Society of Captives: a study of a maximum security prison. Nova York: Princeton University Press.

TAIT, Sarah. (2011), A typology of prison officer approaches to care. European Journal of Criminology, 8, 6: 440-454.

THOMPSON, Augusto FG. (1980), A questão penitenciária. Rio de Janeiro: Forense, 1980.

WASSERMAN, Stanley; FAUST, Katherine. (1994), Social network analysis: Methods and applications. Cambridge: Cambridge University Press.

WHEELER, Stanton. (1961), Socialization in correctional communities. American Sociological Review, 26, 5: 697-712.

ZIMBARDO, Philip. (2007), O efeito Lúcifer: como pessoas boas se tornam más. Rio de Janeiro: Record. 


\section{AGENTES PENITENCIÁRIOS APRISIONADOS EM SUAS REDES?}

\author{
Ludmila Mendonça Lopes Ribeiro, \\ Victor Neiva e Oliveira, Neylson \\ Crepalde, Luiza Meira Bastos e Yolanda \\ Campos Maia
}

Palavras-chave: Agentes penitenciários; Redes egocentradas; RMBH; Trabalho custodial; Aprisionamento.

Neste trabalho, investigamos os componentes das redes pessoais de agentes prisionais e problematizamos se a maior restrição ao ambiente custodial pode ser vista como um efeito do trabalho em penitenciárias. Para tanto, foram utilizadas as entrevistas em profundidade (realizadas entre 2015 e 2017), com presos e agentes da Regiáo Metropolitana de Belo Horizonte (RMBH), e os questionários sociométricos aplicados a esses mesmos sujeitos. A partir desses dados, comparamos as redes pessoais dos agentes penitenciários com as dos presos, e utilizamos os seus discursos sobre padrôes de interação, dentro e fora da prisão, para entendimento das configuraçôes assumidas. Com isso, constatamos que, muitas vezes, os funcionários do cárcere têm redes mais restritas ao universo prisional, do que os próprios internos, o que é descrito por tais entrevistados como um processo de aprisionamento decorrente do trabalho custodial.

\section{CORRECTIONAL OFFICERS IMPRISONED IN THEIR NETWORKS?}

Ludmila Mendonça Lopes Ribeiro, Victor Neiva e Oliveira, Neylson Crepalde, Luiza Meira Bastos and Yolanda Campos Maia

Keywords: correctional officers, egocentric networks; Belo Horizonte Metropolitan Region (RMBH), custodial work, imprisonment.

In this paper, we investigate the components of prison officers' personal networks and inquire whether the larger restriction on the custodial environment may be seen as an effect of their work in prisons. In order to do so, we used indepth interviews (conducted between 2015 and 2017) with agents and captives from the Belo Horizonte Metropolitan Region (RMBH), and sociometric questionnaires applied to these same subjects. From this data, we compared the correctional officers' personal networks with those of the incarcerated, and used their speeches on interactions patterns, both inside and outside of the prison, to understand the accepted configurations. Thereby, we found out that prison staff often have a network more restricted than the inmates themselves, which is described by the interviewees as an imprisonment process derived from custodial work.

\section{LES AGENTS PÉNITENTIAIRES PRIS À LEURS PROPRES FILETS ?}

\author{
Ludmila Mendonça Lopes Ribeiro, \\ Victor Neiva e Oliveira, Neylson \\ Crepalde, Luiza Meira Bastos et Yolanda \\ Campos Maia
}

Mots-clés: Agents pénitentiaires; Réseaux égocentrés; RMBH; Travail de garde; Emprisonnement.

Dans ce travail, nous étudions les composantes des réseaux personnels d'agents pénitentiaires et nous problématisons si la restriction la plus importante par rapport à l'environnement de mise en garde peut être considérée comme un effet du travail dans les prisons. Pour cela, nous avons utilisé des entretiens approfondis (réalisés entre 2015 et 2017), avec des prisonniers et des agents de la région métropolitaine de Belo Horizonte (RMBH), en employant des questionnaires sociométriques appliqués à ces mêmes sujets. À partir de ces données, nous avons comparé les réseaux personnels des agents pénitentiaires avec ceux des prisonniers, et nous avons utilisé leurs discours sur les modèles d'interaction, tant à l'intérieur qu'à l'extérieur de la prison, en vue de comprendre les paramètres employés. Grâce à cela, nous avons constaté que, souvent, les agents pénitenciers possèdent des réseaux plus restreints à l'univers carcéral que les propres internes, ce qui est décrit par les personnes interviewées comme un processus d'emprisonnement résultant du travail de garde. 
